\title{
Restoration of Rivers Used for Timber Floating: Effects on Riparian Plant Diversity
}

James M. Helfield

Western Washington University, james.helfield@wwu.edu

Samantha Capon

Monash University

Christer Nilsson

Umeå universitet

Roland Jansson

Umeå universitet

Daniel Palm

Umeå universitet

Follow this and additional works at: https://cedar.wwu.edu/esci_facpubs

Part of the Environmental Sciences Commons

\section{Recommended Citation}

Helfield, James M.; Capon, Samantha; Nilsson, Christer; Jansson, Roland; and Palm, Daniel, "Restoration of Rivers Used for Timber Floating: Effects on Riparian Plant Diversity" (2007). Environmental Sciences Faculty and Staff Publications. 17.

https://cedar.wwu.edu/esci_facpubs/17 


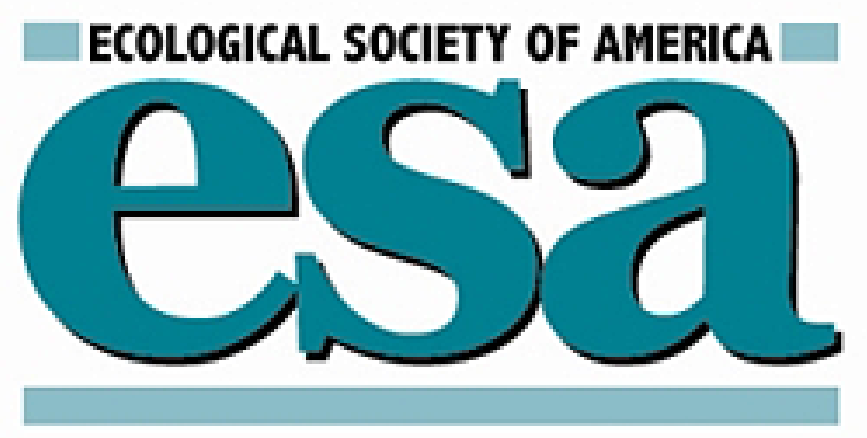

Restoration of Rivers Used for Timber Floating: Effects on Riparian Plant Diversity Author(s): James M. Helfield, Samantha J. Capon, Christer Nilsson, Roland Jansson and Daniel Palm

Source: Ecological Applications, Vol. 17, No. 3 (Apr., 2007), pp. 840-851

Published by: Ecological Society of America

Stable URL: http://www.jstor.org/stable/40061845

Accessed: 20/11/2014 12:50

Your use of the JSTOR archive indicates your acceptance of the Terms \& Conditions of Use, available at http://www.jstor.org/page/info/about/policies/terms.jsp

JSTOR is a not-for-profit service that helps scholars, researchers, and students discover, use, and build upon a wide range of content in a trusted digital archive. We use information technology and tools to increase productivity and facilitate new forms of scholarship. For more information about JSTOR, please contact support@ jstor.org. 


\title{
RESTORATION OF RIVERS USED FOR TIMBER FLOATING: EFFECTS ON RIPARIAN PLANT DIVERSITY
}

\author{
James M. Helfield, ${ }^{1,4}$ Samantha J. Capon, ${ }^{2}$ Christer Nilsson, ${ }^{1}$ Roland Jansson, ${ }^{1}$ and Daniel Palm ${ }^{3}$ \\ ${ }^{\prime}$ Landscape Ecology Group, Department of Ecology and Environmental Science, Umeå University, SE-901 87 Umeå, Sweden \\ ${ }^{2}$ School of Biological Sciences, Monash University, Clayton, Victoria, 3800 Australia \\ ${ }^{3}$ Department of Aquaculture, Swedish University of Agricultural Sciences, SE-901 83 Umeå, Sweden
}

\begin{abstract}
Fluvial processes such as flooding and sediment deposition play a crucial role in structuring riparian plant communities. In rivers throughout the world, these processes have been altered by channelization and other anthropogenic stresses. Yet despite increasing awareness of the need to restore natural flow regimes for the preservation of riparian biodiversity, few studies have examined the effects of river restoration on riparian ecosystems. In this study, we examined the effects of restoration in the Ume River system, northern Sweden, where tributaries were channelized to facilitate timber floating in the 19th and early 20th centuries. Restoration at these sites involved the use of heavy machinery to replace instream boulders and remove floatway structures that had previously lined stream banks and cut off secondary channels. We compared riparian plant communities along channelized stream reaches with those along reaches that had been restored 3-10 years prior to observation. Species richness and evenness were significantly increased at restored sites, as were floodplain inundation frequencies. These findings demonstrate how river restoration and associated changes in fluvial disturbance regimes can enhance riparian biodiversity. Given that riparian ecosystems tend to support a disproportionate share of regional species pools, these findings have potentially broad implications for biodiversity conservation at regional or landscape scales.
\end{abstract}

Key words: biodiversity; boreal; flooding; fuvial disturbance; forest; restoration; riparian; river; Sweden; timber floating; vegetation.

\section{INTRODUCTION}

Riparian zones are among the most ecologically important features of the landscape. In addition to regulating the structure and dynamics of aquatic ecosystems (Meehan et al. 1977, Gregory et al. 1991, Naiman and Décamps 1997), riparian ecosystems enhance regional species richness by supporting disproportionately large numbers of species (Naiman et al. 1993, Nilsson and Jansson 1995, Goebel et al. 2003) or by supporting distinct communities of species (Sabo et al. 2005) in comparison with adjacent upland habitats. Consequently, processes controlling productivity and species composition in riparian zones may exert an important influence on biodiversity at regional and landscape scales.

The dominant processes structuring riparian ecosystems tend to be fluvial disturbances such as flooding and sediment deposition. Patterns of disturbance control species richness in a variety of terrestrial and aquatic ecosystems (e.g., Connell 1978), although the distur-

Manuscript received 28 February 2006; revised 18 August 2006; accepted 24 August 2006; final version received 18 September 2006. Corresponding Editor: E. H. Stanley.

${ }^{4}$ Present address: Department of Environmental Sciences, Huxley College of the Environment, Western Washington University, Bellingham, Washington 98225-9181 USA. E-mail: james.helfield@wwu.edu bance-diversity relationship may be positive, negative, or unimodal (Mackey and Currie 2001, Li et al. 2004). In riparian ecosystems, the most species-rich communities have been found to occur at sites with intermediate levels of flood frequency and high levels of spatial variation in flood frequency (Pollock et al. 1998, Bagstad et al. 2005). Frequent low-intensity floods limit competitive exclusion by dominant species and create open patches for colonization by opportunistic species (Nilsson and Grelsson 1990, Auble and Scott 1998). In contrast, infrequent floods of high intensity or duration may denude large areas of riparian vegetation by dislodging or burying plants (Bendix 1999) or by creating anaerobic soil conditions (Blom and Voesenek 1996, Friedman and Auble 1999). Local-scale flooding and sediment deposition also affect soil composition and nutrient dynamics (Richards 1982, Naiman and Décamps 1997, Naiman et al. 1998) and facilitate the dispersion of riparian propagules (Nilsson et al. 1991, Andersson et al. 2000, Jansson et al. 2005).

In rivers throughout the world, these processes have been impaired. Due in large part to anthropogenic changes in fluvial disturbance regimes, riparian ecosystems are among the world's most threatened (Tockner and Stanford 2002). Yet despite increasing awareness of the need to restore natural flow regimes for the preservation of riparian biodiversity, few studies have examined the effects of river restoration on riparian 
FIG. 1. Upstream-looking view of restoration works at Bergvatten rapids on Bjurbäcken, a stream channelized for timber floating in northern Sweden. (A) Before restoration. The channel on the left has been widened and straightened with explosives for use as a floatway. Boulders have been removed and incorporated into a structure cutting off the channel on the right, which receives water only during high flows (Nilsson et al. 2005). (B) After restoration. The dividing structure has been dismantled, boulders have been replaced, and water flow has been restored to both channels. Photo credit: Niclas Hjerdt.

plant communities. The restoration of rivers used for timber floating in northern Sweden offers an opportunity to examine these effects.

Before timber could be transported on roads (ca. 1850-1970), the Swedish forest industry used rivers and streams for transporting logs to coastal mills. To facilitate more efficient log transport, streams were cleared of boulders and large woody debris and levees of stone and wood were constructed to line banks and cut off secondary channels and meander bends (Törnlund 2002, Törnlund and Östlund 2002). In most cases, boulders removed from channels were placed on river banks either haphazardly or as part of the floatway structure. Consequences of such channelization works include simplified channel morphologies, more homogeneous flow regimes, and decreased flood frequencies
(Muotka and Laasonen 2002, Muotka et al. 2002, Nilsson et al. 2005), although rivers channelized for timber floating generally continue to support viable populations of fish and aquatic invertebrates (Lepori et al. 2005a).

In recent years, local authorities have begun to restore channelized streams in the Ume and Pite River systems, using heavy machinery to replace instream boulders and remove floatway structures (Fig. 1; see also Plate 1). The main objective of restoration is to enhance aquatic habitat for Atlantic salmon (Salmo salar), brown trout (S. trutta), and European grayling (Thymallus thymallus), but these actions are also expected to influence riparian habitats. The removal of boulders and floatway structures from the riparian zone exposes fine-grained soils and creates new areas for plant colonization (J. M. 
Fig. 2. Study sites in the Ume River system. Sweden. The gray shading delineates the river's catchment area. Dashed lines indicate the boundaries of Västerbotten County.

Helfield, R. Jansson, and C. Nilsson, personal observations). The removal of floatway levees should also allow more frequent disturbance of riparian habitats that had previously been shielded from all but the most infrequent, catastrophic floods. At the same time, the replacement of boulders within the stream channel is expected to increase channel roughness and flow resistance, resulting in more variable flow regimes and more frequent and spatially heterogeneous patterns of flooding (Nilsson et al. 2005).

Here we present a comparison of riparian vegetation at channelized and restored streams in the Ume River system. We hypothesized that restored sites would exhibit more frequent fluvial disturbance and correspondingly more diverse riparian plant communities. To evaluate this hypothesis, we measured patterns of flood frequency, species richness, evenness, and plant cover at channelized and restored sites in a paired design. The objectives of this study were to assess the effects of river restoration on riparian plant communities and, in so doing, to elucidate the relationship between changes in fluvial regimes and riparian biodiversity.

\section{Methods \\ Study sites}

The Ume River originates in the Scandes Mountains on the border between Sweden and Norway, discharging into the Gulf of Bothnia $\sim 450 \mathrm{~km}$ to the southeast $\left(63^{\circ} 49^{\prime} \mathrm{N}, 20^{\circ} 15^{\prime} \mathrm{W}\right.$; Fig. 2). In this boreal region, upland vegetation is predominantly dry to mesic managed forest dominated by Pinus sylvestris and Picea abies, with an understory of dwarf shrubs (e.g., Vacinium spp. and Empetrum nigrum), mosses, and lichens. Bands of riparian vegetation are comparatively species rich and, although narrow, often exhibit distinct zonation where river banks are gently sloped (Nilsson et al. 1994, 2002). Stands of Betula spp. and Alnus incana occur at higher elevations, shrub communities dominated by Salix spp. occur in intermediate areas, and diverse graminoid and forb communities occupy the lower levels directly bordering stream channels. Floodplain soils in the upper reaches are predominantly peat and morainic substrates, with the proportion of finer sediments increasing downstream. The annual growing season ranges from $<140$ days at the headwaters to nearly 170 days at the river’s mouth (Ångström 1974).

The Ume River system comprises two major channels (Umeälven and Vindelälven) and their tributaries. Tributaries are geomorphologically complex and typically contain fast-flowing turbulent reaches (i.e., rapids) interspersed with slow-flowing tranquil reaches (Nilsson et al. 2002). Water levels in these tributaries fluctuate rapidly in response to precipitation, and high-intensity floods occur in spring following snowmelt. Over the last 
century, the majority of rapids in the Ume River system were channelized for timber floating.

Study sites were located in the riparian zones of second- to fourth-order tributaries. Seven pairs of channelized and restored sites were selected, with each pair located on a different tributary (Abmobäcken, Dergabäcken, Maltan, Ramsan, Staggbäcken, Tannbäcken, Vällingträskbäcken; Fig. 2). These streams have previously been characterized in terms of the effects of restoration on fish and aquatic invertebrate communities and organic matter dynamics (Lepori et al. 2005a, $b$ ). The paired design was chosen to minimize the effects of potentially confounding differences in valley shape, soil composition, water chemistry, and fluvial regime. Criteria for site selection included (1) a relatively straight, rapid reach; (2) conditions considered to be representative of channelized and restored states; (3) restoration to have occurred between 3 and 10 years prior to observation; (4) riparian vegetation not denuded or fragmented by timber harvesting, grazing, or other anthropogenic influences; (5) pairs separated by no more than $5 \mathrm{~km}$ of stream length; and (6) water-level regimes unaffected by dams. Since streams that were used for timber floating generally do not have unimpacted reaches and since unimpacted streams were typically bypassed by the log drivers because they were too narrow or steep (Törnlund 2002, Törnlund and Östlund 2002 ) and are therefore not comparable to channelized and restored streams, it was not possible to include pristine (i.e., unmodified) streams in this study.

At each site, a $50 \mathrm{~m}$ long reach was delineated at random, and the more gently sloping bank was chosen for data collection. Four transects were spaced evenly along each reach, originating at the edge of the bankfull channel and extending laterally into the riparian zone for $15 \mathrm{~m}$. At one site (Maltan Restored), it was necessary to place a single transect on the opposite bank due to interference by a forest road. Study sites were then characterized in terms of bankfull channel width, stream gradient, bank gradient, aspect, and overstory composition. Bankfull width was measured with a fiberglass tape at intervals of $5 \mathrm{~m}$ along each reach. Stream gradient was measured along the course of each reach with a hand-held clinometer. Bank gradient was measured along each transect, also with a hand-held clinometer. Aspect was quantified as deviation, in degrees, from north-facing. Overstory composition was measured by recording the species, diameter at breast height ( $\mathrm{dbh}$ ), and distance from the bankfull edge of all trees and shrubs $>2 \mathrm{~m}$ in height within an area of $5 \times 15 \mathrm{~m}$ encompassing each transect. Basal area was then calculated as the sum of the basal areas of individual overstory plants measured at each site divided by the total area surveyed at that site (i.e., $4 \times 5 \times 15 \mathrm{~m}$ ). Individual basal area values were calculated from dbh measurements (i.e., basal area $=\pi \times$ $\left.[\mathrm{dbh} / 2]^{2}\right)$. Physical and biotic characteristics of channelized and restored sites were compared using paired $t$ tests or, where data were not normally distributed, Wilcoxon signed-ranks tests.

\section{Vegetation surveys}

Vegetation was surveyed in August and September 2003. Along each transect, six quadrats of $1 \mathrm{~m}^{2}$ were established at distances of $0-1 \mathrm{~m}, 1-2 \mathrm{~m}, 2-3 \mathrm{~m}, 4-5 \mathrm{~m}$, 9-10 $\mathrm{m}$, and 14-15 $\mathrm{m}$ from the bankfull edge. Within each quadrat, the percent cover of all vascular plant species was recorded, along with the percentage of substrate occupied by boulders. Only plants $<2 \mathrm{~m}$ in height were included in analyses of species composition, as the time since restoration was judged to be too short to have influenced the distributions of overstory trees.

Vegetation data were analyzed at site and plot (i.e., quadrat) scales. At the site scale, species richness was calculated as the total number of species encountered within all of the $1-\mathrm{m}^{2}$ quadrats at each site. Differences between channelized and restored sites were analyzed with a paired $t$ test. Site-scale species abundance values were expressed as the total area (in square meters) covered by each species at each site, as calculated from cover percentages observed in all of the $1-\mathrm{m}^{2}$ quadrats at each site. One-way analysis of similarities (ANOSIM) was then used to calculate the mean Bray-Curtis dissimilarity in species composition between channelized and restored sites, and similarity percentage (SIMPER) analyses were used to assess the percentage contribution of each species to the overall dissimilarity between the two treatments. ANOSIM and SIMPER analyses were conducted on nonstandardized, untransformed abundance data using PRIMER for Windows version 5.2.9 (PRIMER-E, Plymouth, UK).

At the plot scale, we analyzed patterns of species richness, total plant cover, and dominance (i.e., the inverse of evenness). Plot-scale species richness was calculated as the number of species encountered within each quadrat. Total plant cover was calculated as the sum of cover percentages recorded for all species within each quadrat. Dominance was calculated by dividing the cover percentage of the most abundant species within each quadrat by the total plant cover of that quadrat. Multiplication by 100 then provided a number between 0 and 100 , with higher levels of dominance indicated by values approaching 100 (May 1975). Plant species were then classified according to life form as either (1) graminoids, (2) forbs, (3) dwarf shrubs, or (4) trees and shrubs, and plot-scale species richness and cover values were calculated for each group. Percentage of substrate occupied by boulders was also analyzed at the plot scale.

Plot-scale data were analyzed using a split-plot analysis of variance (ANOVA) model with "river" (i.e., tributary) and "treatment" (i.e., channelized vs. restored) treated as between-subjects (i.e., between transects) factors and "distance" (i.e., quadrat) as a within-subjects factor (Quinn and Keough 2002). "Distance" and "treatment" were fixed factors while 
TABLE 1. Physical and biotic characteristics of study sites.

\begin{tabular}{lcrrc}
\hline \hline \multicolumn{1}{c}{ Site characteristic } & Channelized sites & Restored sites & $t_{\mathrm{df}}$ or $Z_{n 1, n 2}$ & $P$ \\
\hline Mean bankfull channel width $(\mathrm{m})$ & $9.8 \pm 1.3$ & $14.3 \pm 0.7$ & $t_{6}=3.96$ & $0.007^{*}$ \\
Mean stream gradient (\%) & $1.4 \pm 0.1$ & $1.7 \pm 0.2$ & $Z_{7,7}=1.36$ & 0.173 \\
Mean bank gradient (\%) & $7.8 \pm 0.8$ & $5.9 \pm 1.0$ & $Z_{7.7}=1.21$ & 0.225 \\
Deviation from north-facing ( $\left.{ }^{\circ}\right)$ & $90.0 \pm 17$ & $102.9 \pm 16$ & $t_{6}=0.55$ & 0.604 \\
Overstory basal area (m ${ }^{2} /$ ha) & $8.3 \pm 1.3$ & $9.5 \pm 1.1$ & $t_{6}=1.12$ & 0.307 \\
Species richness of riparian plants & $39.7 \pm 1.8$ & $45.6 \pm 1.6$ & $t_{6}=2.97$ & $0.025^{*}$ \\
\hline
\end{tabular}

Notes: Data are mean values \pm SE. Asterisks $\left(^{*}\right)$ indicate significant differences between channelized and restored sites, as determined by two-tailed paired $t$ tests or Wilcoxon signed rank $(Z)$ tests $(\alpha=0.05)$. Study sites were located in the riparian zones of second- to fourth-order tributaries of the Ume River system, Sweden.

"river" and "transect" were considered to be random. Analyses of normality and homogeneity of variance did not suggest the need for any data transformations. The split-plot ANOVA model was constructed using SYSTAT version 10 (SPSS, Chicago, Illinois, USA).

\section{Fluvial disturbance}

To determine whether fluvial disturbance regimes differed between channelized and restored sites, we used temperature as a surrogate for flooding. Temperature loggers (32K Optic StowAway TidBit, Onset Computer Corporation, Pocasset, Massachusetts, USA) were installed at six of the seven pairs of study reaches (i.e., at every tributary but Abmobäcken). At each site, temperature loggers were anchored to the ground's surface along a single transect, at the center of a series of $1-\mathrm{m}^{2}$ quadrats corresponding to the $0-1 \mathrm{~m}, 1-2 \mathrm{~m}, 2-3$ $\mathrm{m}$, and 4-5 $\mathrm{m}$ quadrats used for the vegetation survey. At each site, an additional reference logger was secured to a tree branch $\geq 1.5 \mathrm{~m}$ above the ground surface to record ambient air temperatures, and another reference logger was anchored to a position within the permanently wetted channel, $30-50 \mathrm{~cm}$ above the stream bed, to record stream water temperatures. Loggers were programmed to record temperatures at 1-h intervals during the months of September, October, and November 2004. Data downloaded from the loggers were plotted on a series of line graphs with time (resolution $=$ $1 \mathrm{~h}$ ) on the $x$-axis and temperature (resolution $=0.2^{\circ} \mathrm{C}$ ) on the $y$-axis. These graphs were then analyzed visually to identify periods of flooding. A quadrat was deemed to have been inundated during periods of time when temperatures recorded at the ground surface in that quadrat (1) deviated from the pattern of temperatures recorded by the corresponding air reference, (2) followed the pattern of temperatures recorded by the corresponding water reference, and (3) were consistently within $0.5^{\circ} \mathrm{C}$ of temperatures recorded by the corresponding water reference. Since bank slopes were not equal at all sites, temperature loggers positioned at identical distances from the stream edge recorded data at varying elevations above baseflow water levels. Consequently, these data reflect the effects of high flows on vegetation communities in each quadrat, but not on river stage.

Flood frequencies for each quadrat were expressed in terms of number of flood events per 90 days and percentage of time flooded (i.e., the total duration of flood events as a percentage of the time of observation). These data were analyzed using a randomized block design ANOVA with "treatment" and "distance" as fixed factors and "river" as the random factor (i.e., blocking variable). These analyses were conducted using SPSS 11.0 for Windows (SPSS, Chicago, Illinois, USA).

\section{RESULTS}

\section{Background site characteristics}

Among background site characteristics, only bankfull width differed significantly between channelized and restored sites (Table 1). At the plot scale, the percentage of substrate occupied by boulders was substantially higher in quadrats at channelized sites than at restored sites and also differed significantly between rivers and distances (Fig. 3, Table 2). Significant interaction effects were detected between "river" and "distance" as well as between all three factors, but these did not appear to account for much of the variation in comparison with the strong effect of "treatment."

\section{Total plant cover and species richness}

At the plot scale, total plant cover tended to be lower at channelized sites than at restored sites, particularly at distances of 1-2 m, 2-3 m, and 4-5 m (Fig. 4). However, due to substantial differences in total plant cover between rivers and significant interaction effects between

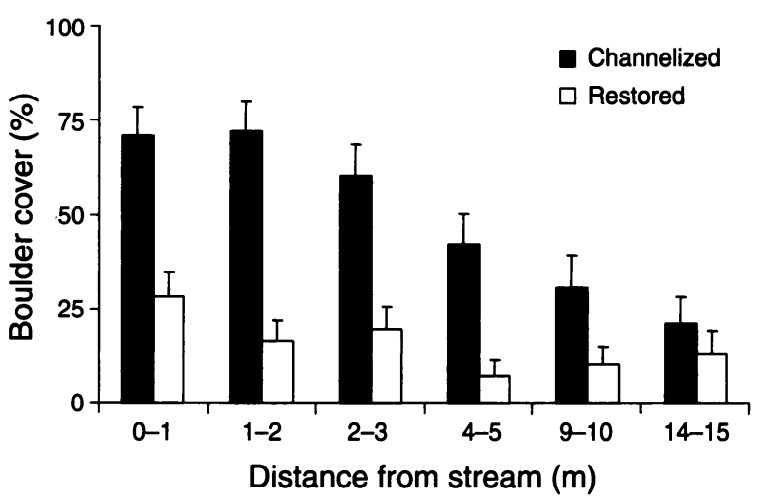

FIG. 3. Percentage of substrate occupied by boulders within $1-\mathrm{m}^{2}$ quadrats at each distance from the stream at channelized and restored sites (mean $+\mathrm{SE}$ ). 
TABLE 2. Summary of ANOVA table examining differences between channelized and restored sites in percentage of substrate occupied by boulders.

\begin{tabular}{lrrr}
\hline \hline \multicolumn{1}{c}{ Source } & \multicolumn{3}{c}{ Boulder cover } \\
\cline { 3 - 5 } & df & \multicolumn{1}{c}{$F$} & $P$ \\
\hline Between subjects & & & \\
$\quad$ River & 6 & 5.79 & $<0.001$ \\
Treatment & 1 & 37.61 & 0.001 \\
River $\times$ treatment & 6 & 1.26 & 0.295 \\
Transect (river $\times$ treatment) & 42 & 2.62 & $<0.001$ \\
Within subjects & & & \\
Distance & 5 & 7.21 & $<0.001$ \\
River $\times$ distance & 30 & 1.88 & 0.006 \\
Treatment $\times$ distance & 5 & 2.45 & 0.057 \\
River $\times$ treatment $\times$ distance & 30 & 2.02 & 0.001 \\
Error & 210 & & \\
\hline
\end{tabular}

"river" and "treatment," this trend was not statistically significant (Table 3). A similar but much stronger trend was evident for species richness, which was significantly higher in restored sites (Fig. 4, Table 3). Species richness was also significantly influenced by distance, with declines occurring at 9-10 $\mathrm{m}$ and further reductions at 14-15 $\mathrm{m}$, although this varied between rivers as indicated by the significant two-way interaction term (Table 3). Differences in species richness between channelized and restored sites were evident at all distances from the stream, as evidenced by the lack of a significant interaction effect between "treatment" and "distance" (Table 3), although these appeared greatest at the intermediate distances of 1-2 $\mathrm{m}, 2-3 \mathrm{~m}$, and 4-5 m (Fig. 4). A significant three-way interaction between "river," "treatment," and "distance" was detected in the analysis, but the low $F$ value suggests that this would account for little of the variability. Site-scale species richness (i.e., the total number of species encountered at each site) was significantly higher at restored sites relative to channelized sites (Table 1).

\section{Dominance}

Similar species tended to dominate at all sites, although these varied with distance from the channel. Dominant species in the 0-1 m, 1-2 m, 2-3 m, and 4-5 m quadrats were predominantly grasses (e.g., Molinia caerulea, Calamagrostis purpurea, and Deschampsia cespitosa) and sedges (i.e., Carex spp.). The forb Filipendula ulmaria also dominated plant cover in many of the quadrats located within these distances. Plant cover in the 9-10 $\mathrm{m}$ and $14-15 \mathrm{~m}$ quadrats was most commonly dominated by the dwarf shrubs Vaccinium vitis-idaea, V. myrtillus, and Lycopodium spp. and, less frequently, by the grass Festuca ovina. Although this composition of dominant species did not vary substantially between sites, the degree to which these species dominated plant cover was significantly influenced by "river," "distance," and "treatment" (Table 3). Significant three-way interaction between these terms was evident, but here too the low $F$ value indicates that little of the variability can be accounted for by this. "Treatment" had the greatest effect on dominance with "distance" exerting a secondary influence. Dominance was significantly higher in quadrats at channelized sites for all distances, with the exception of $0-1 \mathrm{~m}$, and tended to be greater in quadrats further from the stream (Fig. 5). The most marked difference in dominance between channelized and restored sites was apparent in the 4-5 m quadrats.

\section{Species composition}

We found no significant dissimilarity in species composition between channelized and restored sites (ANOSIM global $R=0.074, P=0.19$ ). SIMPER analyses indicated a mean dissimilarity of 51.77 between the two groups. The only species to account for $>5 \%$ of that dissimilarity was the purple moor grass $M$. caerulea (5.97\%), which was more abundant at channelized sites than at restored sites.

Among the plant groups defined by life form, forbs were the only group to exhibit significant differences in cover or richness between channelized and restored sites (Table 4). Both cover and richness of forbs were significantly higher in restored sites and declined significantly with increasing distance from the channel (Fig. 6). Quadrats at $0-1 \mathrm{~m}$ appeared to exhibit the least amount of difference in forb cover and richness between channelized and restored sites. Due to significant differences between rivers, significant interaction be-
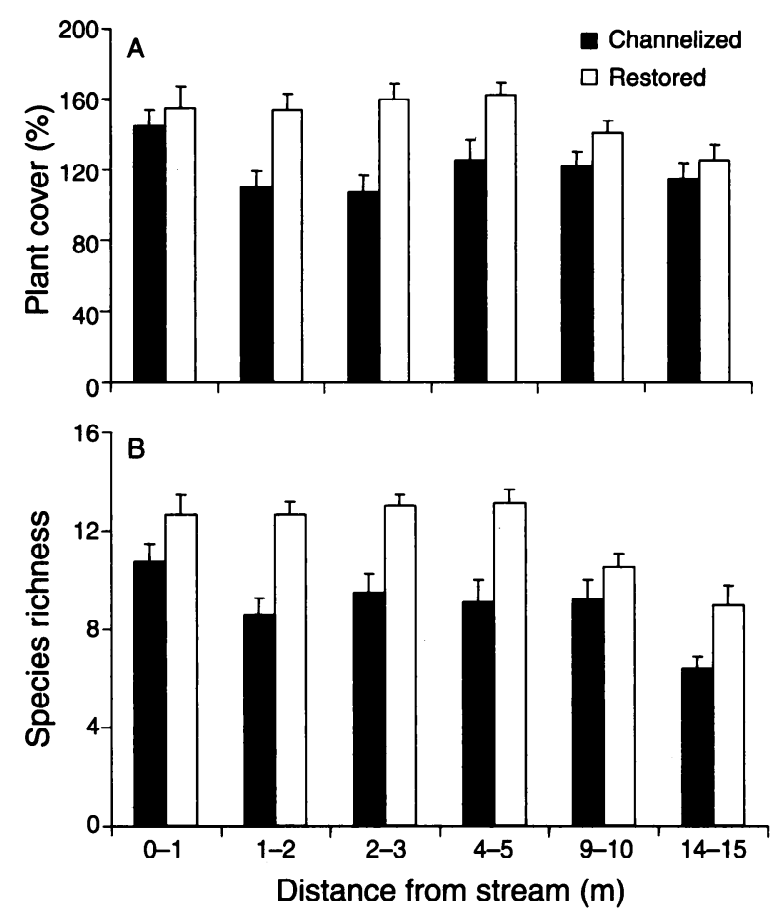

Fig. 4. (A) Total plant cover and (B) species richness (mean number of species within $1-\mathrm{m}^{2}$ quadrats at each distance from the stream) at channelized and restored sites (mean $+\mathrm{SE})$. 
TABLE 3. Summary of ANOVA table examining differences between channelized and restored sites in total plant cover, species richness, and dominance of riparian vegetation.

\begin{tabular}{|c|c|c|c|c|c|c|c|c|c|}
\hline \multirow[b]{2}{*}{ Source } & \multicolumn{3}{|c|}{ Total plant cover } & \multicolumn{3}{|c|}{ Species richness } & \multicolumn{3}{|c|}{ Dominance } \\
\hline & $\mathrm{df}$ & $F$ & $P$ & $\overline{\mathrm{df}}$ & $F$ & $P$ & df & $F$ & $P$ \\
\hline \multicolumn{10}{|l|}{ Between subjects } \\
\hline River & 6 & 5.07 & 0.001 & 6 & 1.43 & 0.226 & 6 & 2.88 & 0.019 \\
\hline Treatment & 1 & 5.57 & 0.056 & 1 & 15.12 & 0.008 & 1 & 26.42 & 0.002 \\
\hline River $X$ treatment & 6 & 3.41 & 0.008 & 6 & 2.12 & 0.071 & 6 & 0.77 & 0.598 \\
\hline Transect (river $\times$ treatment) & 42 & 2.82 & $<0.001$ & 42 & 2.51 & $<0.001$ & 42 & 2.03 & 0.001 \\
\hline \multicolumn{10}{|l|}{ Within subjects } \\
\hline Distance & 5 & 1.84 & 0.135 & 5 & 5.85 & 0.001 & 5 & 4.63 & 0.003 \\
\hline River $\times$ distance & 30 & 3.61 & 0.004 & 30 & 2.31 & $<0.001$ & 30 & 1.45 & 0.071 \\
\hline Treatment $x$ distance & 5 & 2.51 & 0.052 & 5 & 1.23 & 0.319 & 5 & 1.57 & 0.199 \\
\hline River $\times$ treatment $\times$ distance & 30 & 1.44 & 0.075 & 30 & 1.68 & 0.019 & 30 & 1.66 & 0.022 \\
\hline Error & 210 & & & 210 & & & 208 & & \\
\hline
\end{tabular}

tween "river" and "distance" was evident in the analysis of both variables (Table 4). A significant three-way interaction between all factors was also apparent, but here too $F$ values were comparatively low. This significant interaction effect was probably due to the large differences in forb cover between rivers, as there was no significant interaction between "distance" and "treatment" or between "river" and "treatment" (Table 4). Although no significant patterns were found in the cover or richness of the graminoid plant group with relation to "treatment" (Table 4), both of these also tended to be lower in channelized sites (Fig. 6). This was particularly noticeable in terms of graminoid cover in quadrats at 1-2 $\mathrm{m}, 2-3 \mathrm{~m}$, and $4-5 \mathrm{~m}$ from the channel (Fig. 6). In the analyses, these patterns appear to have been masked by significant differences between rivers resulting in significant interactions between "river" and "treatment" (Table 4). Although dwarf shrubs displayed a strong pattern of increasing cover and richness with increasing distance, little effect of "treatment" was apparent in this or the tree and shrub plant group (Fig. 6, Table 4).

\section{Fluvial disturbance}

Analyses of temperature data suggest that 8 of the 12 sites observed (three of six channelized, five of six restored) experienced at least one flood event during the autumn of 2004. Data were not recovered from two loggers due to malfunction. Of the 46 quadrats from which data were recovered, 19 were influenced by at least one flood event ( 5 of 23 channelized, 14 of 23 restored). Flood frequencies were significantly increased at restored sites relative to channelized sites (Fig. 7, Table 5). This pattern was evident in all quadrats instrumented with data loggers, but was most pronounced in quadrats closest to the stream.

\section{Discussion}

The results presented here demonstrate that plant species richness and evenness are significantly enhanced at restored sites relative to channelized sites. The fact that flood frequencies were also increased at restored sites supports the hypothesis that these differences are due to changes in fluvial disturbance regimes following restoration. Analyses of background site characteristics indicate no systematic differences in channel morphology or riparian habitat among channelized and restored sites that might account for observed patterns of diversity (Table 1). Channel width was significantly greater at restored sites, but this is most likely a consequence of restoration rather than a confounding variable (Lepori et al. 2005b, Nilsson et al. 2005). Similarly, the fact that boulders occupied a smaller percentage of riparian substrate at restored sites is likely a direct consequence of restoration efforts.

It is possible that observed differences in riparian diversity are due, to some extent, to the short-term effects of removing floatway structures and creating new areas for plant colonization. If so, these differences should be most evident in areas formerly occupied by boulders and/or floatway structures (i.e., plots closest to the stream). The fact that total cover and diversity of understory plants were enhanced in restored plots at all distances from the stream suggests the influence of broader-scale phenomena such as changes in fluvial disturbance regime.

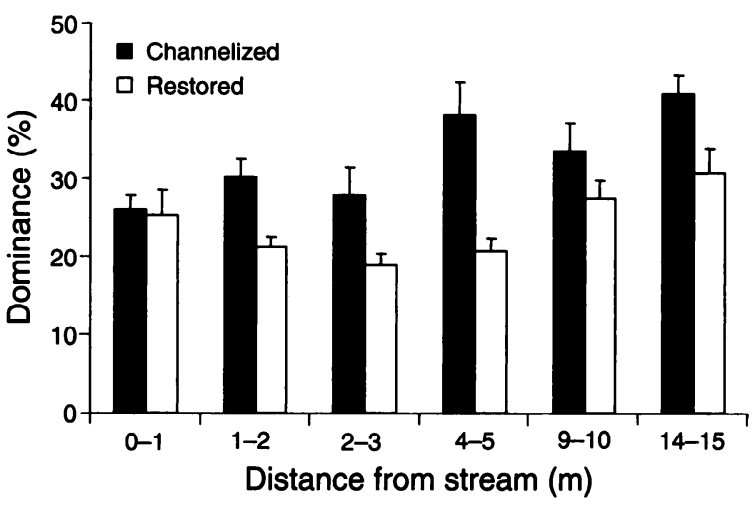

FIG. 5. Dominance within $1-\mathrm{m}^{2}$ quadrats at each distance from the stream at channelized and restored sites (mean $+\mathrm{SE}$ ). 
TABLE 4. Summary of ANOVA table examining differences between channelized and restored sites in cover and species richness of plant groups.

\begin{tabular}{|c|c|c|c|c|c|}
\hline \multirow[b]{2}{*}{ Source } & \multirow[b]{2}{*}{ df } & \multicolumn{2}{|c|}{ Cover } & \multicolumn{2}{|c|}{ Richness } \\
\hline & & $F$ & $P$ & $F$ & $P$ \\
\hline \multicolumn{6}{|l|}{ Graminoids } \\
\hline \multicolumn{6}{|l|}{ Between subjects } \\
\hline River & 6 & 5.68 & $<0.001$ & 2.63 & 0.030 \\
\hline Treatment & 1 & 2.75 & 0.149 & 5.62 & 0.055 \\
\hline River $\times$ treatment & 6 & 2.63 & 0.030 & 2.96 & 0.017 \\
\hline Transect (river $\times$ treatment) & 42 & 3.17 & $<0.001$ & 1.71 & 0.008 \\
\hline \multicolumn{6}{|l|}{ Within subjects } \\
\hline Distance & 5 & 7.08 & $<0.001$ & 4.55 & 0.003 \\
\hline River $\times$ distance & 30 & 2.90 & $<0.001$ & 2.27 & $<0.001$ \\
\hline Treatment $\times$ distance & 5 & 2.23 & 0.077 & 0.99 & 0.438 \\
\hline River $\times$ treatment $\times$ distance & 30 & 1.73 & 0.014 & 1.55 & 0.042 \\
\hline Error & 210 & & & & \\
\hline \multicolumn{6}{|l|}{ Forbs } \\
\hline \multicolumn{6}{|l|}{ Between subjects } \\
\hline River & 6 & 9.09 & $<0.001$ & 5.17 & $<0.001$ \\
\hline Treatment & 1 & 18.90 & 0.005 & 16.02 & 0.007 \\
\hline River $\times$ treatment & 6 & 1.64 & 0.160 & 1.51 & 0.199 \\
\hline Transect (river $\times$ treatment) & 42 & 2.64 & $<0.001$ & 3.01 & $<0.001$ \\
\hline \multicolumn{6}{|l|}{ Within subjects } \\
\hline Distance & 5 & 9.68 & $<0.001$ & 12.31 & $<0.001$ \\
\hline River $\times$ distance & 30 & 2.77 & $<0.001$ & 2.35 & $<0.001$ \\
\hline Treatment $\times$ distance & 5 & 0.29 & 0.913 & 0.61 & 0.695 \\
\hline River $\times$ treatment $\times$ distance & 30 & 1.74 & 0.014 & 1.53 & 0.047 \\
\hline Error & 210 & & & & \\
\hline \multicolumn{6}{|l|}{ Dwarf shrubs } \\
\hline \multicolumn{6}{|l|}{ Between subjects } \\
\hline River & 6 & 6.56 & $<0.001$ & 8.87 & $<0.001$ \\
\hline Treatment & 1 & $<0.01$ & 0.992 & 0.28 & 0.617 \\
\hline River $\times$ treatment & 6 & 3.21 & 0.011 & 5.13 & $<0.001$ \\
\hline Transect (river $\times$ treatment) & 42 & 2.54 & $<0.001$ & 2.62 & $<0.001$ \\
\hline \multicolumn{6}{|l|}{ Within subjects } \\
\hline Distance & 5 & 32.54 & $<0.001$ & 25.64 & $<0.001$ \\
\hline River $\times$ distance & 30 & 2.49 & $<0.001$ & 1.41 & 0.088 \\
\hline Treatment $\times$ distance & 5 & 0.91 & 0.490 & 0.74 & 0.601 \\
\hline River $\times$ treatment $\times$ distance & 30 & 2.30 & $<0.001$ & 1.86 & 0.007 \\
\hline Error & 210 & & & & \\
\hline \multicolumn{6}{|l|}{ Trees and shrubs } \\
\hline \multicolumn{6}{|l|}{ Between subjects } \\
\hline River & 6 & 2.05 & 0.080 & 0.95 & 0.470 \\
\hline Treatment & 1 & 0.98 & 0.361 & 1.26 & 0.304 \\
\hline River $\times$ treatment & 6 & 2.29 & 0.053 & 1.15 & 0.351 \\
\hline Transect (river $\times$ treatment) & 42 & 1.91 & 0.002 & 2.45 & $<0.001$ \\
\hline \multicolumn{6}{|l|}{ Within subjects } \\
\hline Distance & 5 & 1.84 & 0.135 & 2.45 & 0.056 \\
\hline River $\times$ distance & 30 & 2.09 & 0.001 & 1.63 & 0.026 \\
\hline Treatment $\times$ distance & 5 & 0.71 & 0.619 & 2.79 & 0.035 \\
\hline River $\times$ treatment $\times$ distance & 30 & 0.88 & 0.648 & 0.63 & 0.936 \\
\hline Error & 210 & & & & \\
\hline
\end{tabular}

It can be difficult to separate the mechanisms by which fluvial disturbance affects riparian biodiversity. In addition to limiting competitive exclusion by dominants as described by the intermediate disturbance hypothesis (Connell 1978), flooding and sediment deposition influence species distributions by contributing nutrients to riparian soils (Naiman and Décamps 1997, Naiman et al. 1998) and facilitating the dispersal of riparian propagules (Nilsson et al. 1991, Andersson et al. 2000, Jansson et al. 2005). Some combination of these mechanisms is likely at work, but four lines of evidence suggest the importance of competition in this study: (1) The fact that species composition did not differ significantly between channelized and restored sites suggests subtle differences in competitive dynamics rather than wholesale differences in habitat characteristics or recruitment. Similarly, the fact that channelized and restored sites tended to be dominated by the same species, even if the degree of dominance varied, suggests that increased flood frequency affects competition and 

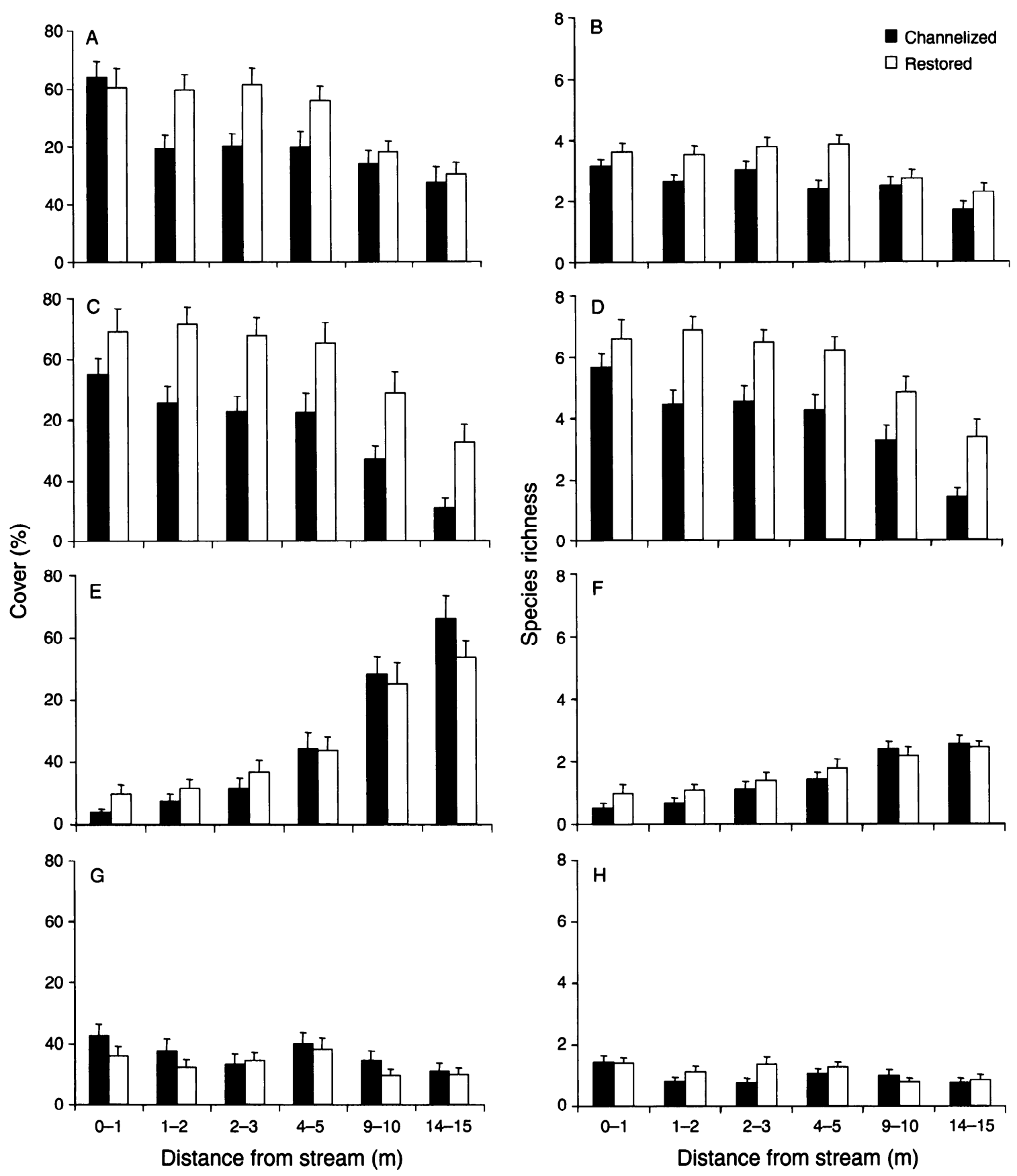

FIG. 6. Cover and richness (mean number of species within $1-\mathrm{m}^{2}$ quadrats at each distance from the stream) of (A, B) graminoid, (C, D) forb, (E, F) dwarf shrub, and $(G, H)$ tree and shrub plant groups at channelized and restored sites (mean + SE). See Methods for a description of the dominance calculations.

dominance within existing species pools to a greater extent than it alters habitat conditions or introduces new species. (2) The species that accounted for the greatest proportion of the dissimilarity in species composition between channelized and restored sites ( $M$. caerulea $)$ is a competitive dominant that grows in clumps and tends to exclude other species in the absence of frequent disturbance (Chambers et al. 1999, El-Kahloun et al.
2000, Marrs et al. 2004). That it was more abundant at channelized sites suggests an increase in competitive advantage due to less frequent flooding. (3) The similarity of basal area densities at channelized and restored sites suggests that changes in flood frequency have not resulted in any systematic differences in nutrient capital or site productivity. (4) The fact that dominance was greatest in plots furthest from the stream 

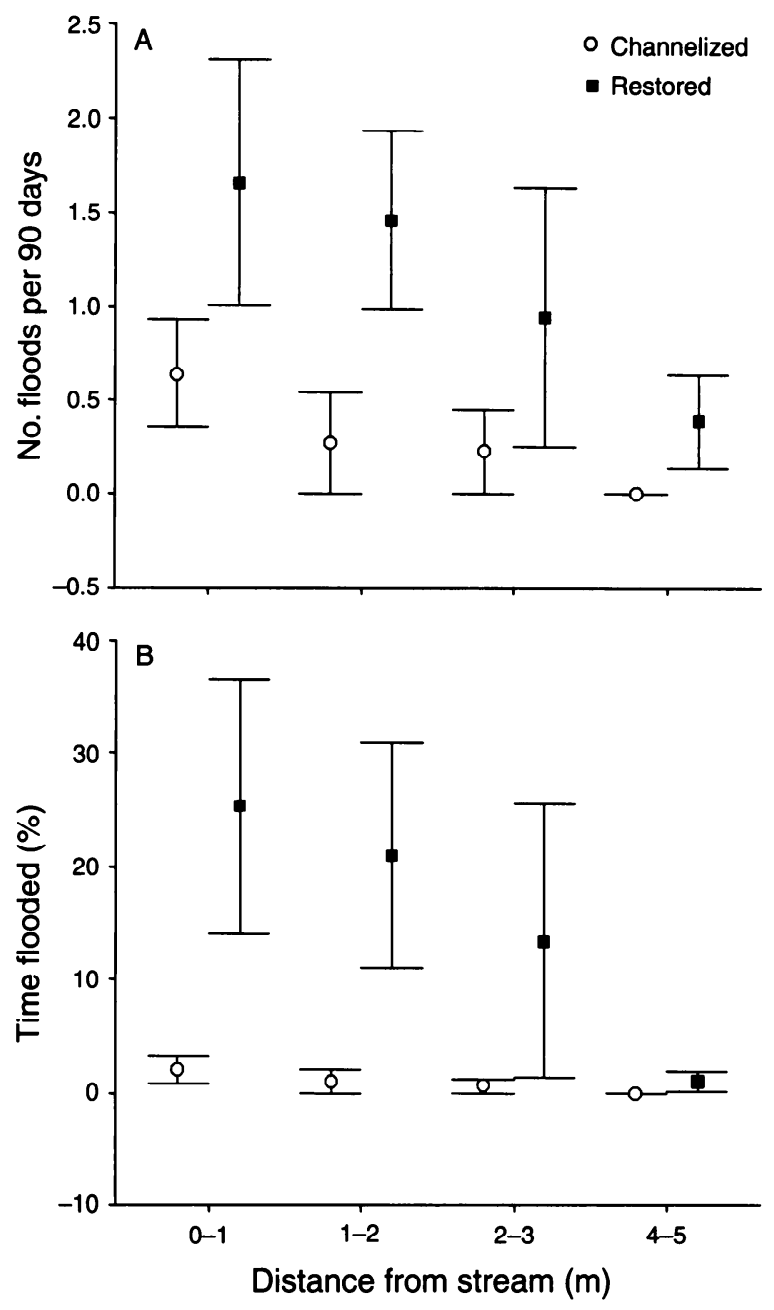

Fig. 7. (A) Number of floods per 90 days and (B) percentage of time flooded as a function of distance from the stream at channelized and restored sites (mean $\pm \mathrm{SE}$ ).

at both channelized and restored sites is further evidence of the importance of flood frequency in limiting competitive exclusion.

Flood data were recorded during autumn, when seasonal rains typically give rise to moderately high flows. Observed patterns of flood frequency are likely representative of rainfall-driven floods in autumn and summer, but might not be representative of snowmeltdriven spring floods, which are typically greater in intensity and duration. Spring floods are more likely to overwhelm floatway constructions and extend deeper into the riparian zone and might therefore affect channelized and restored sites more equally. However, we suggest that these relatively large-scale floods are less likely to influence patterns of riparian diversity than are small- and intermediate-scale disturbances caused by autumn and summer and floods, which tend to be more spatially variable and create more heterogeneous patches within the riparian zone (see Pollock et al. 1998). The disturbance processes most likely to influence riparian diversity may therefore be the ones most likely to be influenced by restoration. Alternatively, spring floods might differ between channelized and restored sites and influence riparian diversity in the same way that autumn and summer floods do. The fact that restored sites exhibited increased diversity at the plot scale as well as the site scale suggests that within-site patch heterogeneity might not be as important as between-site variation in flood frequency in influencing observed patterns of riparian diversity.

At one channelized site (Dergabäcken) and two restored sites (Maltan, Vällingträskbäcken), flood events were observed in late autumn, after mean daily air temperatures had dropped to below $0^{\circ} \mathrm{C}$ and ice had formed on the stream. Field observations indicated that these events were not caused by rainfall, but were likely caused by the formation of ice dams within the stream. The resulting floodwaters then froze in the riparian zone and persisted throughout the winter. Since these ice floods persisted beyond the period of observation, calculations of percentage of time flooded at these sites likely underestimate annual values. It is not clear to what extent such ice floods affect riparian vegetation. Evergreen species such as Juniperus communis and $V$. vitis-idaea might be adversely affected by freezing or scouring or they might benefit from being insulated by the ice. Nonetheless, these winter disturbances are spatially variable within the riparian zone and have the potential to affect site-scale patterns of species composition and diversity. As with summer and autumn flooding, winter flooding may be increased at restored sites due to the absence of floatway structure levees and increased abundance of channel roughness features such as boulders and woody debris, which aid in the formation of ice dams (J. M. Helfield, personal observation).

TABLE 5. Summary of ANOVA tables examining differences between channelized and restored sites in floods per 90 days and percentage of time flooded.

\begin{tabular}{|c|c|c|c|c|c|}
\hline \multirow[b]{2}{*}{ Source } & \multirow[b]{2}{*}{$\mathrm{df}$} & \multicolumn{2}{|c|}{ Floods per 90 days } & \multicolumn{2}{|c|}{ Time flooded (\%) } \\
\hline & & $F$ & $P$ & $F$ & $P$ \\
\hline Treatment & 1 & 10.02 & 0.003 & 10.59 & 0.003 \\
\hline Distance & 3 & 2.65 & 0.065 & 1.76 & 0.173 \\
\hline Treatment $\times$ distance & 3 & 0.50 & 0.682 & 1.41 & 0.257 \\
\hline River & 5 & 3.09 & 0.021 & 2.32 & 0.065 \\
\hline Error & 33 & & & & \\
\hline
\end{tabular}


PLATE 1. Excavator removing a floatway structure previously separating a river channel from its riparian zone in northern Sweden. As the barrier is removed, boulders from the structure are relocated to the channel, thereby altering patterns of streamflow and fluvial disturbance. Such changes can enhance riparian biodiversity. Photo credit: C. Nilsson.

\section{CONCLUSIONS}

The idea that riparian restoration is an important strategy for the preservation and enhancement of stream habitat is well established (e.g., Kaufmann et al. 1997, Opperman and Merenlender 2004). The results presented here demonstrate that the reciprocal also holds true: River restoration can be an effective strategy for the enhancement of riparian biodiversity. The relatively short interval since restoration observed in this study (i.e., 3-10 years) suggests that results may be seen relatively quickly, although differences in species richness between channelized and restored sites may increase over time. It is unlikely that restoration will result in new species being introduced at the catchment scale, given that propagules are recruited primarily from upstream reaches, but more frequent disturbance may prevent some rare floodplain species from being outcompeted. It is worth noting that exotic species are largely absent from floodplain habitats in boreal Sweden (Jansson et al. 2000, Dynesius et al. 2004). In more temperate regions, changes in disturbance regimes might facilitate the spread of invasive exotics, and it might be necessary for management agencies to weigh this concern against the potential benefits of increased species richness following restoration. Community responses to restoration will likely vary according to such factors as climate, species composition, channel morphology, and restoration technique. Nonetheless, this study illustrates how manipulation of fluvial regimes can influence riparian species composition. To the extent that riparian ecosystems support a disproportionate share of regional species pools, these findings have potentially broad implications for biodiversity conservation at regional or landscape scales.

\section{ACKNOWLEDGMENTS}

We thank Fabio Lepori and Catherine A. Reidy for valuable contributions and assistance in the field. We also thank Erik Törnlund, Stig Westbergh, Tommy Stenlund, and Daniel Holmqvist for help with the selection of study sites. and Brendan McKie and Gerry Quinn for help with statistical models and analyses. The manuscript was improved by the comments and suggestions of two anonymous reviewers. This study was funded by grants from the Kempe Foundations (to C. Nilsson) and the Swedish Environmental Protection Agency (Naturvårdsverket), through Älvsbyn`s municipality (to C. Nilsson).

\section{Literature Cited}

Andersson. E., C. Nilsson, and M. E. Johansson. 2000. Plant dispersal in boreal rivers and its relation to the diversity of riparian flora. Journal of Biogeography 27:1095-1106.

Ångström, A. 1974. Sveriges klimat. Generalstabens litografiska anstalt. Stockholm, Sweden. [In Swedish.]

Auble, G. T., and M. L. Scott. 1998. Fluvial disturbance patches and cottonwood recruitment along the upper Missouri River, Montana. Wetlands 18:546-556.

Bagstad, K. J., J. C. Stromberg, and S. J. Lite. 2005. Response of herbaceous riparian plants to rain and flooding on the San Pedro River, Arizona. USA. Wetlands 25:210-223.

Bendix, J. 1999. Stream power influence on southern Californian riparian vegetation. Journal of Vegetation Science 10: 243-252. 
Blom, C., and L. Voesenek. 1996. Flooding: the survival strategies of plants. Trends in Ecology and Evolution 11: 290-295.

Chambers, F. M., D. Mauquoy, and P. A. Todd. 1999. Recent rise to dominance of Molinia caerulea in environmentally sensitive areas: new perspectives from paleoecological data. Journal of Applied Ecology 36:719-733.

Connell, J. H. 1978. Diversity in tropical rain forests and coral reefs. Science 199:1302-1310.

Dynesius, M., R. Jansson, M. E. Johansson, and C. Nilsson. 2004. Intercontinental similarities in riparian-plant diversity and sensitivity to river regulation. Ecological Applications 14:173-191.

El-Kahloun, M., D. Boeye, B. Verhagen, and V. Van Haesebroeck. 2000. A comparison of the nutrient status of Molinia caerulea and neighbouring vegetation in a rich fen. Belgian Journal of Botany 133:91-102.

Friedman, J. M., and G. T. Auble. 1999. Mortality of riparian box elder from sediment mobilization and extended inundation. Regulated Rivers: Research and Management 15: 463-476.

Goebel, P. C., B. J. Palik, and K. S. Pregitzer. 2003. Plant diversity contributions of riparian areas in watersheds of the northern Lake States, USA. Ecological Applications 13: 1595-1609.

Gregory, S. V., F. J. Swanson, W. A. McKee, and K. W. Cummins. 1991. An ecosystem perspective of riparian zones. BioScience 41:540-551.

Jansson, R., C. Nilsson, M. Dynesius, and E. Andersson. 2000. Effects of river regulation on river-margin vegetation: a comparison of eight boreal rivers. Ecological Applications 10:203-224.

Jansson, R., U. Zinko, D. M. Merritt, and C. Nilsson. 2005. Hydrochory increases riparian plant species richness: a comparison between a free-flowing and a regulated river. Journal of Ecology 93:1094-1103.

Kauffmann, J. B., R. L. Beschta, N. Otting, and D. Lytjen. 1997. An ecological perspective of riparian and stream restoration in the western United States. Fisheries 22:12-24.

Lepori, F., D. Palm, E. Brännäs, and B. Malmqvist. 2005a Does restoration of structural heterogeneity in streams enhance fish and macroinvertebrate diversity? Ecological Applications 15:2060-2071.

Lepori, F., D. Palm, and B. Malmqvist. 2005b. Effects of stream restoration on ecosystem functioning: detritus retentiveness and decomposition. Journal of Applied Ecology 42: 228-238.

Li, J., W. A. Loneragan, J. A. Duggin, and C. D. Grant. 2004. Issues affecting the measurement of disturbance response patterns in herbaceous vegetation: a test of the intermediate disturbance hypothesis. Plant Ecology 172:11-26.

Mackey, R. L., and D. J. Currie. 2001. The diversitydisturbance relationship: Is it generally strong and peaked? Ecology 82:3479-3492.

Marrs, R. H., J. D. P. Phillips, P. A. Todd, J. Ghorbani, and M. G. Le Duc. 2004. Control of Molinia caerulea on upland moors. Journal of Applied Ecology 41:398-411.

May, R. M. 1975. Patterns of species abundance and diversity. Pages 81-120 in M. L. Cody and J. M. Diamond, editors. Ecology and evolution of communities. Harvard University Press, Cambridge, Massachusetts, USA.

Meehan, W. R., F. J. Swanson, and J. R. Sedell. 1977. Influences of riparian vegetation on aquatic ecosystems with particular reference to salmonid fishes and their food supply. Pages 137-145 in Importance, preservation, and management of riparian habitat: a symposium. USDA Forest Service, Pacific Northwest Forest and Range Experiment Station, Corvallis, Oregon, USA.
Muotka, T., and P. Laasonen. 2002. Ecosystem recovery in restored headwater streams: the role of enhanced leaf retention. Journal of Applied Ecology 39:145-156.

Muotka, T., R. Paavola, A. Haapala, M. Novikmec, and P. Laasonen. 2002. Long-term recovery of stream habitat structure and benthic invertebrate communities from instream restoration. Biological Conservation 105:243-253.

Naiman, R. J., and H. Décamps. 1997. The ecology of interfaces: riparian zones. Annual Review of Ecology and Systematics 28:621-658.

Naiman, R. J., H. Décamps, and M. M. Pollock. 1993. The role of riparian corridors in maintaining regional biodiversity. Ecological Applications 3:209-212.

Naiman, R. J., K. L. Fetherston, S. J. McKay, and J. Chen. 1998. Riparian forests. Pages 289-323 in R. J. Naiman and R. E. Bilby, editors. River ecology and management. Springer-Verlag, New York, New York, USA.

Nilsson, C., E. Andersson, D. M. Merritt, and M. E. Johansson. 2002. Differences in riparian flora between riverbanks and river lakeshores explained by dispersal traits. Ecology 83:2878-2887.

Nilsson, C., A. Ekblad, M. Dynesius, S. Backe, M. Gardfjell, B. Carlberg, S. Hellqvist, and R. Jansson. 1994. A comparison of species richness and traits of riparian plants between a main river channel and its tributaries. Journal of Ecology 82:281-295.

Nilsson, C., M. Gardfjell, and G. Grelsson. 1991. Importance of hydrochory in structuring plant communities along rivers. Canadian Journal of Botany 69:2631-2633.

Nilsson, C., and G. Grelsson. 1990. The effects of litter displacement on riverbank vegetation. Canadian Journal of Botany 68:735-741.

Nilsson, C., and R. Jansson. 1995. Floristic differences between riparian corridors of regulated and free-flowing boreal rivers. Regulated Rivers: Research and Management 11:55-66.

Nilsson, C., F. Lepori, B. Malmqvist, E. Törnlund, N. Hjerdt, J. M. Helfield, D. Palm, J. Östergren, R. Jansson, E. Brännäs, and H. Lundqvist. 2005. Forecasting environmental responses to restoration of rivers used as $\log$ floatways: an interdisciplinary challenge. Ecosystems 8: 779-800.

Opperman, J. J., and A. M. Merenlender. 2004. The effectiveness of riparian restoration for improving instream fish habitat in four hardwood-dominated California streams. North American Journal of Fisheries Management 24: 822-834.

Pollock, M. M., R. J. Naiman, and T. A. Hanley. 1998. Plant species richness in riparian wetlands: a test of biodiversity theory. Ecology 79:94-105.

Quinn, G. P., and M. J. Keough. 2002. Experimental design and data analysis for biologists. Cambridge University Press, Cambridge, UK.

Richards, K. 1982. Rivers: form and process in alluvial channels. Methuen, London, UK.

Sabo, J. L., R. Sponseller, M. Dixon, K. Gade, T. Harms, J. Heffernan, A. Jani, G. Katz, C. Soykan, J. Watts, and J. Welter. 2005. Riparian zones increase regional species richness by harboring different, not more species. Ecology 86: 56-62.

Tockner, K., and J. A. Stanford. 2002. Riverine flood plains: present state and future trends. Environmental Conservation 29:308-330.

Törnlund, E. 2002. Flottningen dör aldrig: bäckflottningens avveckling efter Ume- och Vindelälven 1945-70. [In Swedish.] Dissertation. Umeå University, Umeå, Sweden.

Törnlund, E., and L. Östlund. 2002. The floating of timber in northern Sweden: construction of floatways and transformation of rivers. Environmental History 8:85-106. 